ter during the first divisions of the embryo, after which it begins to divide in basipetal order. When the embryo begins to show cotyledons, the suspensor, with the exception of the so-called "hypophysis,"contains a row of from two to four cells. When the growing cotyledons have given the embryo the characteristic cordate form, the number of suspensor-cells is also found to have been increased. The "Anschlusszelle," or suspensor cell next the embryo, plays a special rôle. The other suspensor cells divide in somewhat irregular fashion, but in this one the first wall is vertical, and vertical divisions follow in planes at right angles to each other. This does not agree with Fleischer's account of Helianthus, in which the Anschlusszelle has two transverse walls before vertical divisions begin. A little later, vertical divisions occur in the cell below the Anschlusszelle. The descendants of these two cells take part in the formation of the embryo, which by this addition has become nearly spherical. - CHAS. CHAMBERLAIN.

\title{
Correlation effects following mechanical hindrance of growth.
}

In a recent contribution on growth-correlations, Dr. Franz Hering $^{1}$ reports some very interesting results. He takes issue with the conclusion reached by $\mathrm{Kny}^{2}$ that the growth of root and shoot of seedlings proceeds with a high degree of independence, and points out that in his study Kny took cognizance only of the end-results of growth through long periods and neglected to look for temporary modifications that were soon concealed by further growth. Hering finds that interdependence between these systems is pronounced. He cites experiments by Stone showing that when the epicotyl was removed from a seedling, the growth rate of the root immediately decreased; after a time, however, it regained and, indeed, surpassed its normal rate, as a result of the increased activity connected with the process of repair. In consequence, the total growth during an extended period would equal of exceed that of the control objects.

By use of Pfeffer's method of confining parts in plaster of Paris casts, the author investigated the action resulting from mechanical hindrance of the growth of a system, or of a part

${ }^{1}$ Ueber Wachsthumscorrelationen in Folge mechanischer Hemmung do

Wachsens. Pringsh. Jahrb. f. wiss. Botanik 29: 132-170. 1896.

Annals of Botany 8: 265 . 1874. 
of a system on adjacent and on remote parts of the plant. When either the root or the shoot system was incased, a plain retardation of the growth of the free system was always seen. This retardation differed somewhat from that observed when the part was simply amputated. Instead of a recovery following the shock from the injury, the author found that the continued irritation from the confined parts caused a likewise continued retardation with a total growth (in the case of the radicle) averaging about two-thirds of that of the control. Upon freeing the confined parts, a plainly marked acceleration of the growth rate of both systems followed.

The cotyledons of Streptocarpus behaved in a very interesting manner. Normally one cotyledon grows until it reaches considerable dimensions. The other, however, remains rudimentary, and finally dies. When the cotyledon in the usual order of things predestined to development was put in the cast, the smaller usually fugacious member assumed the rôle and grew, provided the development of the seedling had not already proceeded too far. A similar result was obtained by the extirpation of the larger cotyledon. Thus the prevention of growth in one part can awaken it in another.

The question of correlation within a particular system was investigated. If the cast was so placed as to leave free the apex and entire growing zone of a radicle, a retarded growth resulted. Neither the revival of growth in old tissues, nor a changed distribution of growth was found to follow the application of the cast preventing normal elongation. When only partially hindered, growth was reduced but not re-localized.

When shoots of various kinds of seedlings were correspondingly treated, the correlation phenomena agreed completely with those seen in roots. Shoots so enclosed that growth in length merely was prevented, grew abnormally in thickness, but on the release from the cast it was resumed in the parts still plastic.

From these results, it appears that, without sufficient development in the sustaining parts, the sustained meristematic regions are unable to make a strong development.R. H. TRUE.

\section{Fertilization of Batrachospermum.}

In the Annals of Botany (March) Dr. Bradley M. Davis has recorded some important results from his study of the fertilization of Batrachospermum. The species chiefly studied was $B$. moniliforme, subsequently checked by a study of two 

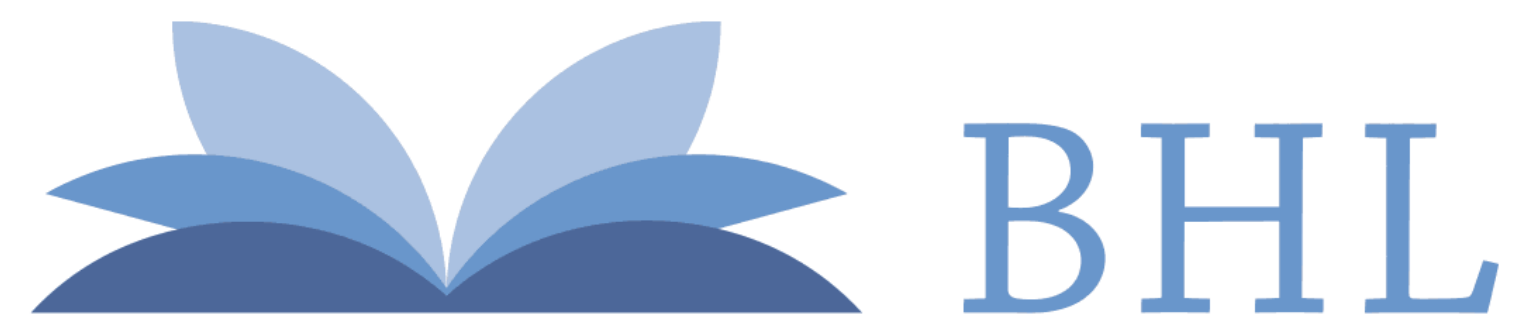

\section{Biodiversity Heritage Library}

True, Rodney H. 1896. "Correlation Effects Following Mechanical Hindrance of Growth." Botanical gazette 21(4), 230-231. https://doi.org/10.1086/327339.

View This Item Online: $\underline{\text { https://www.biodiversitylibrary.org/item/94860 }}$

DOI: https://doi.org/10.1086/327339

Permalink: https://www.biodiversitylibrary.org/partpdf/222608

\section{Holding Institution}

Missouri Botanical Garden, Peter H. Raven Library

\section{Sponsored by}

Missouri Botanical Garden

\section{Copyright \& Reuse}

Copyright Status: Public domain. The BHL considers that this work is no longer under copyright protection.

This document was created from content at the Biodiversity Heritage Library, the world's largest open access digital library for biodiversity literature and archives. Visit BHL at https://www.biodiversitylibrary.org. 